\title{
CAN WE COMBINE STRUCTURAL FUNCTIONALITY AND LANDSCAPE SERVICES ASSESSMENTS IN ORDER TO ESTIMATE THE IMPACT OF LANDSCAPE STRUCTURE ON LANDSCAPE SERVICES?
}

\author{
Hana SKOKANOVÁ
}

\begin{abstract}
This paper investigates two methods of assessing structural functionality and landscape services, and the potential of their joint application in order to estimate the impact of landscape structure in terms of structural functionality on landscape capacity to provide various services. The methods were tested in three different landscape types of the Czech Republic. The results showed that linking these two methods might help in estimating the impact of landscape structure on some landscape services in landscape types with a prevalent valuable matrix, but are dependent on landscape metrics defining individual functionality groups.
\end{abstract}

\section{Shrnutí}

\section{Je možno zkombinovat hodnocení funkčnosti krajiny s hodnocením krajinných služeb pro odhadnutí dopadu struktury krajiny na její služby?}

Tento článek zkoumá dvě metody hodnotící funkčnost struktury krajiny a služby krajiny a potenciál jejich propojení pro odhad dopadu struktury krajiny $z$ hlediska její funkčnosti na kapacitu krajiny poskytovat rüzné služby. Metody byly testovány ve třech rüzných typech krajiny České republiky. Výsledky ukázaly, že propojení těchto dvou metod by mohlo pomoci $k$ odhadu dopadu struktury krajiny na jeji některé služby $v$ typech krajiny s převládajícím cenným prostředim, ale že tyto výsledky jsou závislé na krajinných metrikách, které definují jednotlivé funkční skupiny.

Keywords: landscape assessment, structural functionality, landscape services, landscape metrics, Czech Republic

\section{Introduction}

Landscape is an extremely complex concept of a holistic nature (Naveh, Lieberman, 1994; Antrop, 2000) as it consists of both natural and human-induced components with various interlinks. Present landscapes have been strongly influenced by human activities: namely by urbanization, industrialization, and intensive agriculture which can heavily impact landscape quality in terms of ecological functions and processes, biodiversity, the capacity to provide numerous services useful for humans, etc.

A scientifically sound guidance is needed for planners to address ecological problems associated with urbanization, industrialization or intensive agriculture and to conserve ecosystems in order to halt the loss of biodiversity. Landscape metrics have been widely used as a quantitative and objective tool for planners to lay out reliable planning guidance.
They can be used to indicate ecosystem degradations or disturbances requiring special attention in some regions (Su et al., 2012).

Landscape structure reflects both the natural settings and the impacts of human activities through the centuries (Skokanová, Eremiášová, 2013). It significantly influences ecological functions and processes (see e.g. Tischendorf, 2001; Tscharntke et al., 2002; Dauber et al., 2003) and its key role in the assessment of landscape quality, especially biodiversity and visual quality, has been pointed out in many studies (Kuiper, 1998; Hokit et al., 1999; Weinstoerffer and Girardin, 2000; Bock et al., 2005; Dramstad et al., 2006). In recent decades, landscape structure has very often been a topic of scientific research, which yielded a large amount of papers (Kuttner et al., 2013). Many indices were proposed for the analysis of landscape structure to capture landscape patterns in 
relation to their function (Forman and Godron, 1986). The spatial configuration of landscape elements expressed by landscape metrics indirectly reflects structural functionality, which can be interpreted as a degree of connectivity of landscape elements, and is also referred to as landscape functionality (Kuttner et al., 2013; Skokanová, Eremiášová, 2013).

Besides the assessment of structural functionality, reflecting the spatial configuration of landscapes, we can also assess what goods and services a landscape can provide. Ecosystem services are quantified and valued by ecosystem service assessments that are typically trans-disciplinary (Seppelt et al., 2012). The assessment of ecosystem service values should be useful for ecological planners (van der Horst, 2011), given its capacity to combine ecological processes and economic outcomes (Wainger et al., 2010). In order to be widely applied, the data set and methods used for assessing ecosystem services must be easily accessible and lowcost (Su et al., 2012). One of the basic concepts for the assessment of ecosystem services was introduced in the Millennium Ecosystem Assessment (MEA, 2005). It provides a basic framework for assessing the interaction between ecosystems and humans, and how these can be measured, evaluated, and strengthened for future well-being (Hermann et al., 2013). There is an increasing amount of work dealing with mapping, classification and valuation of ecosystem services (e.g. de Groot et al., 2002; Wallace, 2007; Sherrouse et al., 2011), as the issues represent key elements required for integrating this concept into decisionmaking processes (Burkhard et al., 2009; Hermann et al., 2013). The mapping of ecosystem services can be based on land use/land cover classes (Burkhard et al., 2009; Potschin, 2009; Lautenbach et al., 2011), or habitats (Haines-Young and Chopping, 1996; HainesYoung, Potschin, 2008), which are spatially explicit, represent distinct ecological units, and thus could be seen as "bundles" of the services they can deliver (Hermann, Schliefer and Wrbka, 2011).

When dealing with the landscape scale, it might be more appropriate to use the term "landscape services" (Termorshuizen, Opdam, 2009), as they are associated with people's local environments, and are related more to human and cultural patterns, unlike ecosystem services that may be related more to natural processes and conservation (Hermann et al., 2013). The capacity for providing services within an ecosystem is believed to be not homogenously distributed across landscapes, but rather dependent on spatial and temporal interactions between different components $(\mathrm{Ng}$ et al., 2013; Syrbe, Walz, 2012; Willemen et al., 2008). Despite this knowledge, works joining ecosystem services and spatial patterns are rather rare (Frank et al., 2012; Su et al., 2012). A possible approach to account for spatial patterns and their impact on landscape structure-related ecosystem services might be the use of landscape metrics (Feld et al., 2007). Examples of this approach can be found in studies published by Kong et al. (2007), Frank et al. (2012), Su et al. (2012) or Syrbe and Walz (2012). The latter group of authors used landscape metrics to identify the impact of landscape structure on ecosystem services, while $\mathrm{Ng}$ et al. (2013) focused on landscape connectivity, since they believe that not taking into consideration this criterion may lead to a failure in properly accounting for the spatial variability of ecosystem services caused by the dynamics in the landscape configuration $(\mathrm{Ng}$ et al., 2013).

This article presents results from the assessment of structural functionality, landscape services, and their mutual relationship in three different landscape types occurring in the Czech Republic. In particular the following questions are posed: Are there any relationships between structural functionality and landscape services? Namely, can we combine the proposed assessments in order to estimate the impact of landscape structure expressed by structural functionality on landscape services? If so, where would this finding be most valid?

The assessment of structural functionality is based on statistical analysis of landscape metrics, since structural functionality in this article is understood as a degree of connectivity of landscape elements (see above). The assessment of landscape services is based on the use of an expert-driven capacity matrix, showing relationships between landscape elements and selected landscape services.

\section{Materials and methods}

\subsection{Sample sites}

Ten sample sites, on average between 350 and 400 ha in size, were selected (Fig. 1). Their selection was based on two criteria: they included parts of protected areas, and the total area of sealed surfaces did not exceed $10 \%$ of the total area of each sample site.

The sample sites were categorised into three groups, according to their landscape type (LT):

1. Alluvial forested LT (1,036.10 ha) - situated in wide river valleys (150-300 m above sea level) with quaternary sediments (loess, sand, and gravel), fluvisols, and warm to mild climate. Floodplain forests with ash, oak or elm, as well as wet meadows, are also common in this LT. Settlements occur to a greater extent in two of the case studies belonging to this LT; 
2. Hilly agricultural LT (1,281.93 ha) - situated in hilly regions at lower elevations (180-300 m a.s.l.) with calcareous clays and sands, chernozems, and warm and dry climate. The prevalent land use is mainly vineyards or arable land, but dry grasslands and oak or oak-hornbeam woodlands occur in protected areas; and

3. Upland meadow forested LT (1662.58 ha) - situated in uplands at higher elevations (300-780 $\mathrm{m}$ a.s.l.) with flysh formations (rotation of sand stones and clay stones, usually in calcareous forms), cambisols, and mild climate. Oak-hornbeam or beech forests predominate, but mesophile meadows are also widespread. Settlements occur to a greater extent in two of the case studies belonging to this LT.

\subsection{Landscape element maps}

Orthophotos from 2009, provided by the Ministry of the Environment of the Czech Republic, with a resolution of $1 \mathrm{~m}$, were used to create landscape element maps (Skokanová, Eremiášová, 2013). Landscape elements in this article represent the smallest mappable homogenous units, and are equal to patches in the sense of Forman and Godron (1986). The photos were manually vectorized in ArcGIS software (ESRI, 1999-2008), and landscape elements were delimited. They were then assigned a code that reflected land cover categories, type and intensity of usage, as well as the ecological stability of the depicted elements. The classification of land cover categories was based on methods tested in the Czech Republic (Pellantová, 1994; Vondrušková, 1994) and Slovakia (Petrovič, 2005; Pucherová, 2007).

Ecological stability (similar to hemeroby - see Steinhardt et al., 1999) was used as one of the measures of quality of the landscape elements. It was based on both a digital layer of biotope mapping in the Czech Republic, which was created when the network of NATURA 2000 sites was established, and on field surveys conducted in 2010 and 2011. The classification of ecological stability was based on the concept of Míchal (1994), who defines ecological stability as the ability of an ecological system to sustain itself despite the influence of disturbing elements, and to reproduce its substantial characteristics in conditions of external disturbance. Each landscape element was given a degree of ecological stability from 0 to 5 . A detailed description of the levels is available in Skokanová, Eremiášová (2012).

In total, 83 types of landscape elements were distinguished, falling into the broad categories of arable land, permanent grassland, permanent crop, forest, water area, sealed area, and other areas.

\subsection{Structural functionality}

For calculating structural functionality, the resulting landscape element map was rasterized with a pixel size of $1.5 \mathrm{~m}$. This rasterized layer served for

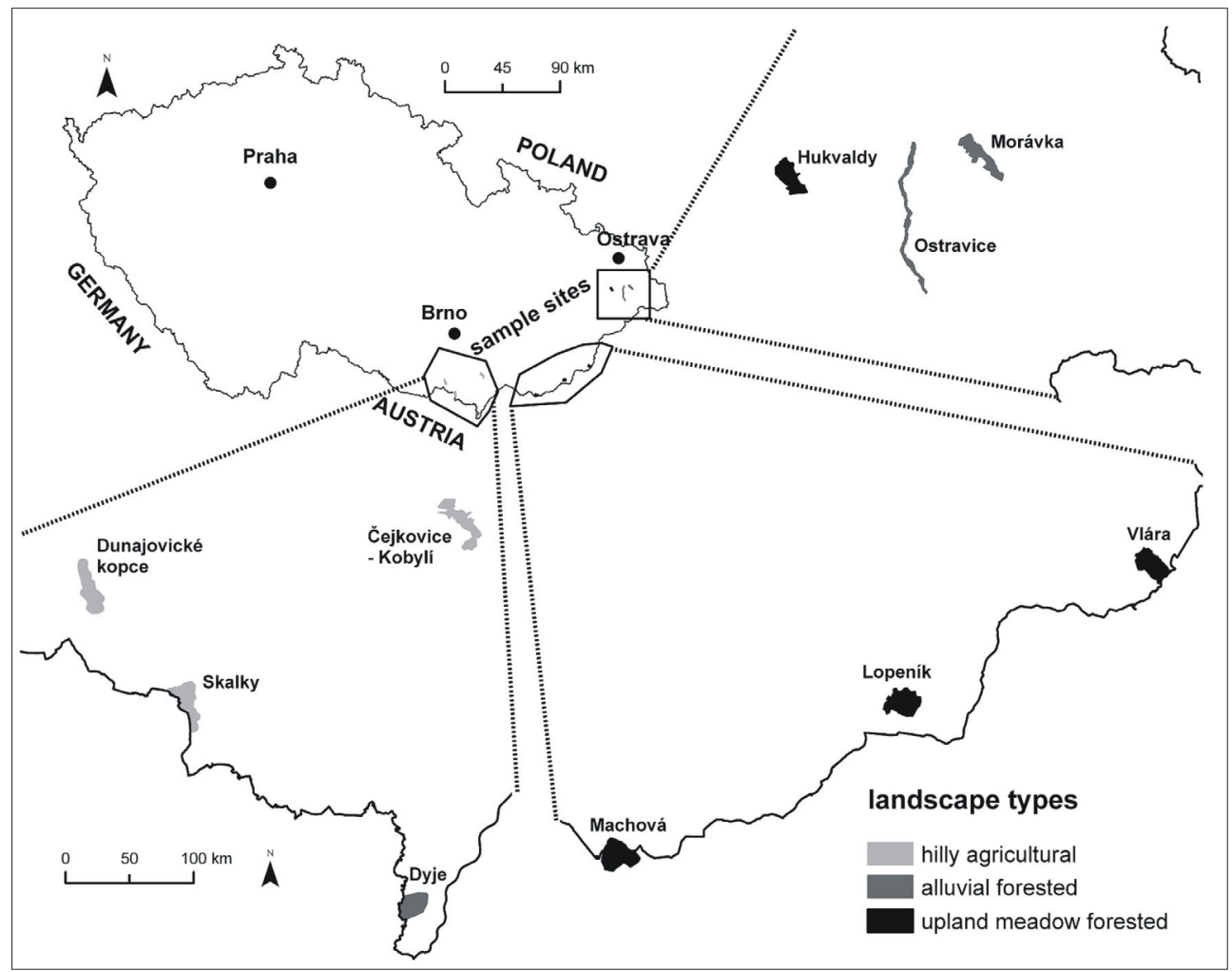

Fig. 1: Location of sample sites in terms of landscape types 
calculating landscape metrics of landscape elements important for the assessment of functionality. Calculation of landscape metrics was carried out using the Fragstats 3.3 programme (McGarigal et al., 2002). Relevant metrics for structural functionality assessment were selected in several steps (for more detail, see Kuttner et al., 2013): first, highly correlated metrics (correlation coefficients of \pm 0.8 ) were selected using the Kendall-Tau method. These were then transformed in order to approximate a Gaussian distribution, and were pooled into six functionality groups reflecting different ecological processes: connecting corridors, dissecting corridors, valuable matrix, disturbed matrix, artificial matrix, and stepping stones (Kuttner et al., 2013; Skokanová and Eremiášová, 2013). Connecting corridors are represented by linear landscape elements that provide connectivity for organisms between other landscape elements (e.g. rivers, tree lines, grassland strips along roads). Dissecting corridors are, on the other hand, artificial linear structures such as roads, railroads, and pipelines. Landscape elements of higher ecological quality, and thus higher conservation value, are recorded in the valuable matrix, whereas landscape elements which are highly anthropogenically influenced belong to the disturbed matrix. The artificial matrix consists of landscape elements with dominant sealed surfaces, such as settlements, industrial areas, and waste dumps. The final functionality group, stepping stones, represents landscape elements that can serve as proxy habitats: examples include abandoned mining sites, fallow land, parks, groups of trees, etc.

For each functionality group a principal component analysis was performed to reveal metrics, which explained the structure in the data to the greatest degree. Predefined relationships between landscape metrics and structural functionality were used for the normalisation of selected metrics (Table 1). These relationships were based on statistical results and were supported by literature (e.g. Cushman et al., 2008; Schindler et al., 2008; Farig, 2003). A positive relationship was defined for cases where increasing values of landscape metrics led to increasing functionality; a negative relationship was defined for cases where increasing values of landscape metrics led to decreasing functionality.

The functionality of landscape elements was calculated as the mean of all normalised indices belonging to the respective functionality group. It was subsequently divided into five functionality categories (very low, low, medium, high, very high) according to the quintile values to derive areal statistics.

\subsection{Landscape services}

The assessed landscape services were adopted from de Groot (2006). In total, 20 individual sub-services were distinguished and grouped into five main services:

\begin{tabular}{|c|c|c|c|c|c|c|}
\hline Landscape metrics & $\begin{array}{c}\text { Connecting } \\
\text { corridors }\end{array}$ & $\begin{array}{l}\text { Dissecting } \\
\text { corridors }\end{array}$ & $\begin{array}{l}\text { Valuable } \\
\text { matrix }\end{array}$ & $\begin{array}{l}\text { Disturbed } \\
\text { matrix }\end{array}$ & $\begin{array}{c}\text { Artificial } \\
\text { matrix }\end{array}$ & $\begin{array}{l}\text { Stepping } \\
\text { stones }\end{array}$ \\
\hline Aggregation index (AI) & & & + & - & & \\
\hline Mean patch area (AREA_MN) & + & - & + & - & & + \\
\hline Class area $(\mathrm{CA})$ & + & - & + & & - & + \\
\hline Connectance index (CONNECT) & + & - & & & & + \\
\hline Mean contiguity index (CONTIG_MN) & & & & & - & \\
\hline Mean core area (CORE_MN) & & & + & - & - & \\
\hline $\begin{array}{l}\text { Area weighted Euclidean nearest- } \\
\text { neighbour distance (ENN_AM) }\end{array}$ & - & + & - & + & + & - \\
\hline $\begin{array}{l}\text { Mean fractal dimension index } \\
\text { (FRAC_MN) }\end{array}$ & + & - & & + & + & \\
\hline Largest patch index (LPI) & & & + & & & \\
\hline Landscape shape index (LSI) & + & - & & & & \\
\hline Patch density (PD) & + & - & & & & + \\
\hline Mean proximity index (PROX_MN) & + & - & + & - & - & + \\
\hline $\begin{array}{l}\text { Area weighted mean shape index } \\
\text { (SHAPE_AM) }\end{array}$ & + & - & + & + & & + \\
\hline
\end{tabular}

Tab. 1: Relationships between functionality groups and landscape metrics in terms of structural functionality (Kuttner et al., 2013). Note: + indicates a positive relationship (i.e. increasing structural functionality with increasing metrics); - indicates a negative relationship (i.e. decreasing structural functionality with increasing metrics) 
regulation, habitat, provision, information, and carrier. Regulation services relate to the capacity of natural and semi-natural ecosystems to regulate essential ecological processes and life-supporting systems through biogeochemical cycles, and maintain a healthy ecosystem at different scale levels (de Groot, 2006). This group includes sub-services such as climate regulation, disturbance prevention, water regulation, water supply, soil retention, soil formation, nutrient regulation, and pollination. Habitat services provide refuge and reproduction habitat for wild plants and animals. They are defined in terms of the minimum critical biotope size needed for a related species. The sub-services of refugium and nursery belong in this group. The provision services are targetting the supply of natural resources (Hermann et al., 2013), while information services include all services contributing to the maintenance of human health, such as opportunities for reflection, spiritual enrichment, recreation, and aesthetic experience. Provision services are in this case represented by food, raw materials, genetic resources, and medicinal resources. Recreation, science, and education were selected for information services. Finally, carrier services describe the capacity of landscapes to provide a suitable substrate for most human activities. As such, we can put sub-services of habitation, cultivation, transportation, and waste disposal into this group. Definitions and examples of the mentioned sub-services are included in de Groot (2006) and Hermann et al. (2013).

The assessment of potential landscape services was based on the use of a capacity matrix (according to Haines-Young, Potschin, 2008; Burkhard et al., 2009), where landscape services were related to a specific landscape element. The relation expressing the capacity of the landscape element to provide a certain landscape service was assessed on a scale from 0 (no relevant link) to 5 (very high relevant link) by expert evaluations from different disciplines of ecology. Values from the capacity matrix were taken from Herman et al. (2013), who used broad habitat types (Essl et al., 2002) as basic units, and adapted for the landscape elements accordingly.

To receive one single value for each sub-service per sample site, mean values of all landscape elements service values were separately calculated for individual sub-services. These were then extrapolated to LT levels by calculating mean values for the related sample sites per LT. Consequently, the main service values were obtained by calculating mean values of the specific subservices on the LT level.

Possible relationships between mean functionality and individual landscape services of the landscape elements at the landscape level were tested using Spearman's rank correlation coefficients in the STATISTICA programme (Statsoft, 2004).

\section{Results}

\subsection{Structural functionality}

The highest structural functionality was calculated for the upland meadow forested LT, while the hilly agricultural LT showed the lowest values of structural functionality. Slightly higher mean functionality was noted for the alluvial forested LT.

In general, the valuable matrix $($ median $=55.62)$ and the connecting corridors (median $=42.44$ ) showed the highest values of mean functionality, while the dissecting corridors $($ median $=48.91$ ) turned out to be lower, but still higher than the disturbed matrix $($ median $=45.86)$, artificial matrix $($ median $=31.62)$, and stepping stones (median $=41.28$ ), as clearly shown in Figure 2a. While these observations were valid for both the alluvial forested and the upland meadow forested landscape types (see Figure $2 \mathrm{~b}$ and d), functionality groups in the hilly agricultural LT tended to behave differently. The differences were typical mainly for the artificial matrix and dissecting corridors - the former showing the highest values of mean functionality and the latter showing the lowest values of mean functionality (Fig. 2c).

The areal distribution of the functionality categories followed a similar pattern as the mean functionality in the functional groups (Tab. 2): Landscape elements such as forests, meadows, and watercourses, belonging to the functionality category "very high", spatially dominated in both forested landscape types. On the other hand, landscape elements from the disturbed matrix (arable land, permanent crops) representing the "very low" functionality category covered more than $50 \%$ of the hilly agricultural LT.

\subsection{Landscape services}

Capacity values of landscape elements to provide main landscape services, i.e. regulation, habitat, provision, information, and carrier, in different landscape types are shown in Fig. 3. As is obvious from this figure, there are only slight differences between the landscape types. Overall, the upland meadow forested LT tended to show higher values for all main services, with the exception of carrier services (Fig. 3c), while the hilly agricultural LT showed the lowest values for all main services, with the exception of provision and regulation services (Fig. 3b). In the alluvial forested LT, carrier services were higher, and provision with regulation services lower than in the other two LT (Fig. 3a). 

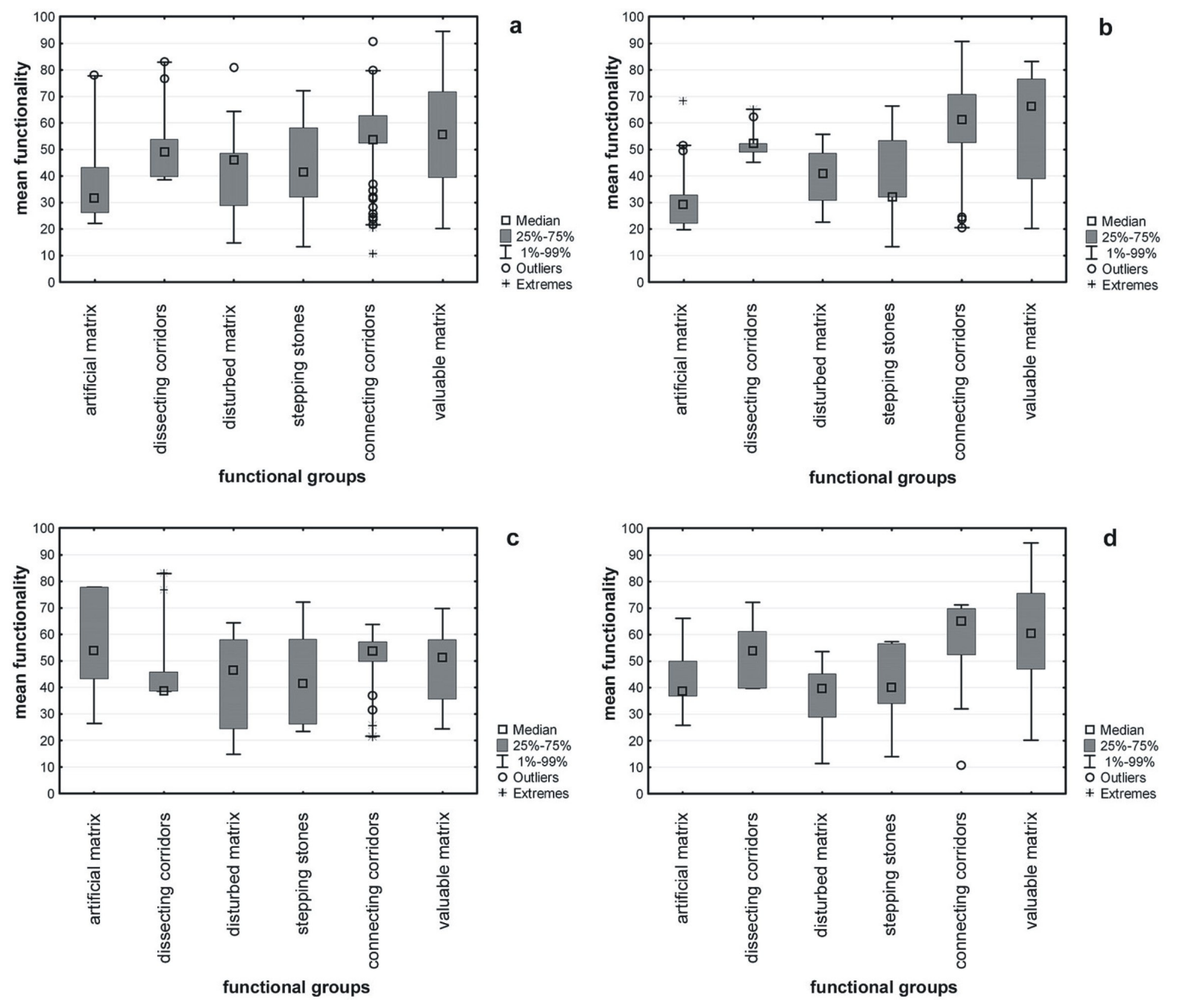

Fig. 2: Mean functionality in functionality groups - overall (a), alluvial forested LT (b), hilly agricultural LT (c), and upland meadow forested $L T(d)$

\begin{tabular}{|l|c|c|c|c|c|}
\hline & Very low & Low & Moderate & High & Very high \\
\hline Alluvial forested LT & 4.7 & 13.3 & 10.2 & 5.5 & 66.3 \\
\hline Hilly agricultural LT & 57.1 & 23.7 & 6.6 & 9.2 & 21.9 \\
\hline Upland meadow forested LT & 5.9 & 1.8 & 7.0 & 6.7 & 79.4 \\
\hline
\end{tabular}

Tab. 2: Area percentage of functionality categories ("very low" to "very high") in the individual landscape types

a

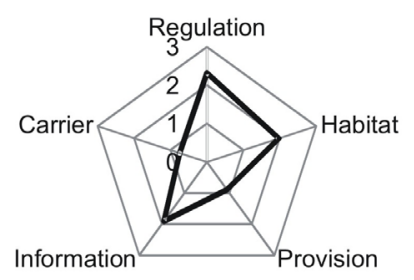

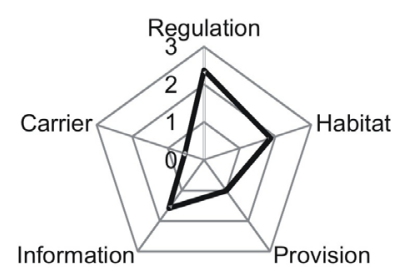

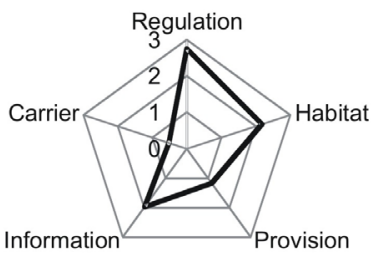

Fig. 3: Capacity values to provide main landscape services in the alluvial forested LT (a), hilly agricultural LT (b), and upland meadow forested $L T$ (c) 
Regulation and habitat services dominated in all landscape types. The highest values were calculated for the upland meadow forested LT. This resulted from a high number of patches of oak-hornbeam and beach forests, as well as herb-rich meadows with higher capacities of the services. A high number of patches of forests and meadows also provided higher capacities for food and medicinal resources from the provision services, and played an important part in the recreation sub-service, which belongs to the information services.

Predominant agricultural use in terms of large and numerous patches of arable fields, vineyards, and intensive orchards in the hilly agricultural LT was reflected in the higher capacity to provide the cultivation sub-service belonging to carrier services. However, since the other sub-services in this group showed very small values, the carrier services group as a total recorded only low values. The number of agricultural patches together with more valuable landscape elements in the form of forest and steppe was also reflected in the higher values of regulation services, namely soil formation, water regulation (Fig. 4), soil retention and nutrient regulation, and habitat services, namely refugium sub-services.

The highest values of carrier services shown in the alluvial forested LT were caused by the concentration of interconnected settlements in the river valleys, which resulted in rather high values of habitation and transportation sub-services. On the other hand, the predominant floodplain forests together with wet meadows provided higher regulation (especially disturbance prevention, pollination, and climate regulation sub-services), information (recreation subservice), and habitat services than was the case of the hilly agricultural LT.

\subsection{Relationships between structural functionality and landscape services}

Spearman's correlation coefficients revealed a significant relationship between structural functionality and the majority of landscape services, especially in the upland meadow forested LT (19 out of 20 sub-services were significantly correlated within the range from -0.288 to +0.494 : see Tab. 3) and in the alluvial forested LT (17 out of 20 sub-services were significantly correlated within the range from -0.499 to +0.540 ). In the hilly agricultural LT, significant correlations were found only for 14 subservices and the values ranged from -0.139 to +0.288 .

It is clear from Tab. 3 that the correlations were rather weak for all landscape types, and only the alluvial forested LT showed a slightly stronger relationship between structural functionality and landscape services, especially regulation, habitat, and provision services. Positive correlations, i.e. increases in the values of mean functionality resulting in the increase of landscape services, were typical for regulation services, habitat services, provision services, and information services in both the alluvial forested and upland meadow forested landscape types. Negative correlation, i.e. landscape services decreasing with increasing structural functionality, was related to the carrier services in both forested LTs and to the majority of sub-services in the hilly agricultural LT.

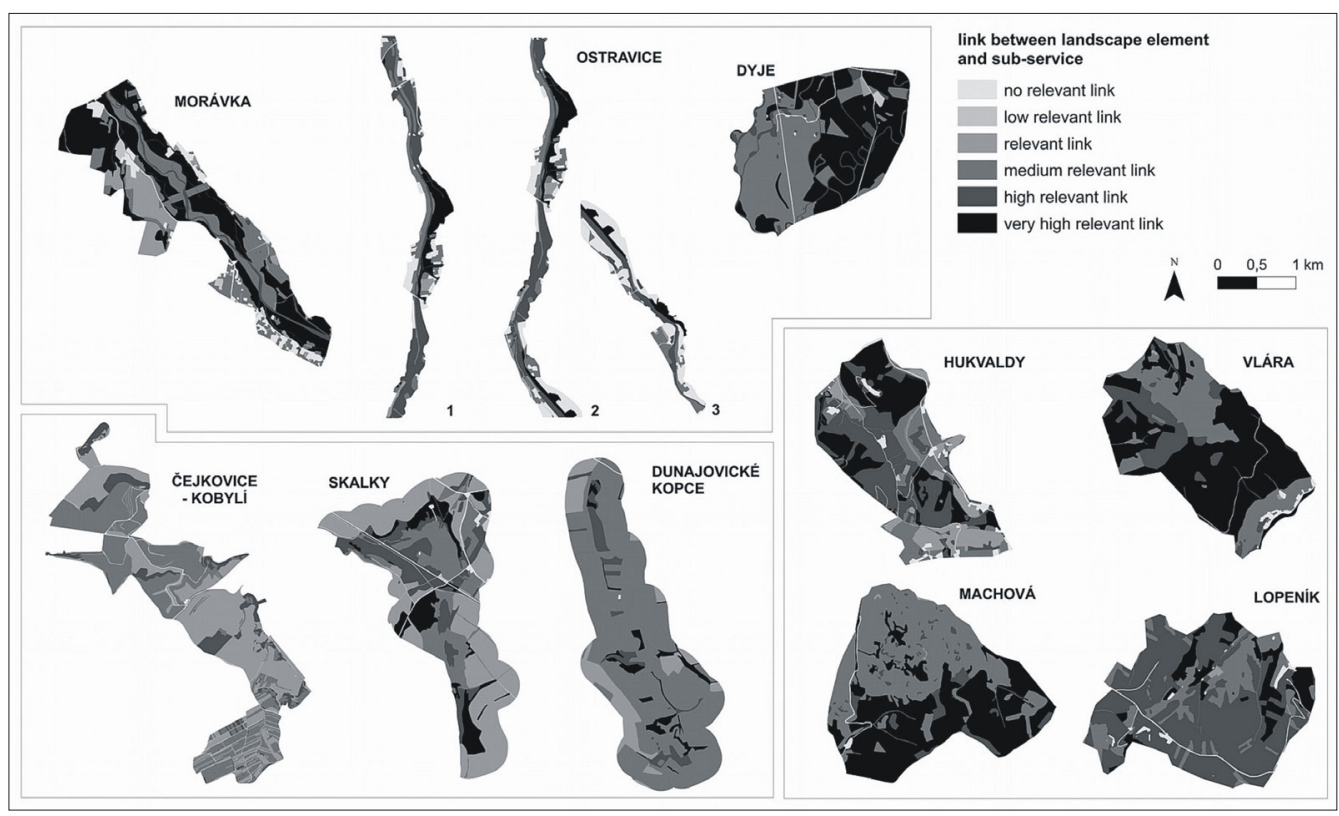

Fig. 4: Water regulation service maps for the alluvial forested LT (upper left), hilly agricultural LT (lower left), and upland meadow forested $L T$ (right) 


\begin{tabular}{|c|c|c|c|c|}
\hline Landscape service & Landscape sub-service & Alluvial forested LT & Hilly agricultural LT & $\begin{array}{l}\text { Upland meadow } \\
\text { forested LT }\end{array}$ \\
\hline \multirow{8}{*}{ Regulation services } & climate regulation & 0.005 & -0.138 & 0.092 \\
\hline & disturbance prevention & 0.473 & 0.001 & 0.454 \\
\hline & soil formation & 0.471 & 0.009 & 0.364 \\
\hline & water regulation & 0.472 & -0.144 & 0.357 \\
\hline & soil retention & 0.442 & -0.049 & 0.305 \\
\hline & nutrient regulation & 0.514 & -0.030 & 0.415 \\
\hline & pollination & 0.370 & 0.372 & 0.094 \\
\hline & water supply & 0.472 & 0.037 & 0.381 \\
\hline \multirow{2}{*}{ Habitat services } & refugium & 0.428 & 0.048 & 0.190 \\
\hline & nursery & 0.501 & 0.180 & 0.319 \\
\hline \multirow{4}{*}{ Provision services } & food & 0.540 & -0.019 & 0.439 \\
\hline & medicinal resources & 0.410 & 0.174 & 0.494 \\
\hline & raw materials & 0.415 & -0.254 & 0.154 \\
\hline & genetic resources & 0.425 & 0.137 & 0.108 \\
\hline \multirow{2}{*}{ Information services } & science and education & 0.361 & -0.181 & 0.419 \\
\hline & recreation & 0.290 & -0.077 & 0.323 \\
\hline \multirow{4}{*}{ Carrier services } & cultivation & -0.041 & -0.132 & -0.153 \\
\hline & habitation & -0.499 & 0.058 & -0.288 \\
\hline & transportation & -0.349 & -0.001 & -0.264 \\
\hline & waste disposal & 0.011 & 0.083 & -0.010 \\
\hline
\end{tabular}

Tab. 3: Spearman correlation coefficients between structural functionality and landscape services in the alluvial forested LT, hilly agricultural LT, and upland meadow forested LT (significant correlations $(p<0.05)$ are marked in bold)

\section{Discussion}

The presented methods for assessing structural functionality and landscape services have their advantages and disadvantages, which are discussed in more detail below.

\subsection{Structural functionality}

For assessing structural functionality, landscape elements were pooled into functionality groups. Distinguishing these groups is very clear, regarding connecting and dissecting corridors - in both cases they are represented by linear elements of long and narrow shapes, while connecting corridors are represented by natural or man-adjusted (e.g. regulated rivers) landscape elements, and dissecting corridors are represented by strictly man-made landscape elements. Also, the artificial matrix is clearly distinguished, since it contains only sealed surfaces. Distinguishing between the valuable matrix and the disturbed matrix is based on the intensity of their usage, reflected also in their degree of ecological stability: while landscape elements in the disturbed matrix are intensively used by man (e.g. large-scale intensive vineyards), human impact and the use of landscape elements in the valuable matrix (e.g. semi- natural meadows) is rather low. As such, if the human impact on landscape elements in the valuable matrix significantly increases, resulting in the decrease of natural species (their presence is less than $30 \%$ ), these elements might be reclassified as a disturbed matrix. On the other hand, if the human impact decreases, landscape elements in the disturbed matrix will first be reclassified as stepping stones. They can be reclassified as a valuable matrix in the end, when the impact of humans will have significantly ceased. This process can be reflected for example in the increased presence of natural species.

The most problematic group to distinguish is represented by stepping stones. Landscape elements of this group can be considered as a step between the disturbed matrix and the valuable matrix, where the intensity of human impact is lower, but still higher than in the valuable matrix, since humans have been affecting the elements for a very long time (decades or even centuries). They include, for example, abandoned orchards, or they were originally made by humans but later left to natural processes (e.g. ponds). The presence of natural species in this group is rather low. Stepping stones are important parts in the landscape, 
because they support species dispersal by decreasing inter-patch distances and providing habitat shelter (Kuttner et al., 2013).

Since the calculation of structural functionality strongly depends on the relationship of the functionality groups with respect to the landscape metrics (Kuttner et al., 2013), it is essential to pool the landscape elements into the correct groups. This can be achieved by applying the above-mentioned rules, which are applicable in different regions of the world. Because this approach needs additional information that is not easily obtainable (e.g. information about the degree of ecological stability or naturalness), the classification by Kuttner et al. (2013), who used CORINE Land Cover classes, can be applied instead.

Calculating structural functionality using the methodology presented here might be biased by the fact that landscape metrics, due to their high number, are often correlated to each other (Wagner and Fortin, 2005; Uuemaa et al., 2009), leading to difficulties in interpretation of the results. Therefore, selecting the most suitable metrics is quite challenging. This can be overcome by various statistical analyses, e.g. factor analysis, principal components analysis and cluster analysis, as was the case in Riiters et al. (1995), Cushman et al. (2008), Schindler et al. (2008) or Kuttner et al. (2013). These analyses make it possible to identify independent components of landscape structure and to group them (Uuemaa et al., 2009).

Besides the landscape metrics, functionality values can be greatly influenced by the number and spatial extent of landscape elements. This was typically the case for the artificial matrix in the hilly agricultural LT, where this functionality group covered the smallest area and had the smallest number of landscape elements, resulting in unbalanced values of the corresponding metrics, hence high functionality values. Similar results were also noted in the Austrian-Hungarian borderland case studies (Kuttner et al., 2013).

A major disadvantage of the current assessment might be seen in the transformation, normalization and aggregation of indices, which may lead to a loss of transparency of the applied method. However, the steps are justifiable: the transformation of input indices was carried out in order to approximate a Gaussian distribution as a necessary precondition for the principal components analysis, which was used to select the most suitable indices explaining relationships within the functionality groups. Further normalization was used to adjust values to a common scale in order to calculate the resulting values of functionality for the given landscape element. It was used because different methods were applied in the transformation of indices: logarithmic, square root, and arcsine square root. Final values of mean functionality per landscape element, which are achieved by averaging the values of normalized indices, reflect the complexity of structural functionality expressed by relevant landscape indices.

The advantages of calculating structural functionality on the basis of landscape metrics lay in simplicity, transparent selection of the landscape metrics, and general applicability. As such, this method might serve as a general guide for both landscape managers and nature conservation authorities for selecting areas suitable for nature conservation and landscape protection (Skokanová, Eremiášová, 2013).

\subsection{Landscape services}

The methodology used for the assessment of potential landscape services can be regarded as simple and generally applicable. Since it does not require intensive new data collection, it can be used especially in regions with limited or incomplete data on specific landscape services (Hermann et al., 2013). The application of a capacity matrix with expert driven values has also been successfully used in other studies (Haines-Young and Potschin, 2008; Burkhard et al., 2009; Hermann et al., 2013). It enables a rapid service assessment and supplies a good overview to see the first trends for landscape service provision (Burkhard et al., 2009). Using a relative five-step scale in assigning capacity values to landscape elements enables a comparison of different capacities to deliver individual sub-services by harmonizing different indicators. It also offers the opportunity to avoid value-laden units, such as monetary terms (Hermann et al., 2013), which are usually quite difficult to establish (see e.g. Seják et al., 2010).

A major drawback of this methodology might be seen in assigning capacity values to landscape elements by expert judgement, which can be subjective. This can be to some extent overcome by incorporating additional data from a field survey, reflecting for example the intensity of usage or ecological quality in the definition of landscape elements, as was the case of this study. Incorporating additional data in the definition of landscape elements also overcomes the problem of distinguishing land cover classes only on the basis of maps derived from orthophotos or satellite imagery. Another approach was shown in the work of Hermann et al. (2013), who defined landscape elements as broad habitat types but revised initial values of the capacity matrix by qualifiers derived from field surveys. 
The capacity to provide some landscape sub-services (e.g. pollination, recreation, water regulation) can be strongly influenced by the spatial and functional position of landscape elements, neighbour effects, landscape element size, etc., as shown in the studies by Lautenbach et al. (2011) or Ng et al. (2013). Other services, such as soil formation or water supply are expected to depend primarily on land use composition (Lautenbach et al., 2011). Hermann et al. (2013) weighted potential capacities by area, assuming that the area of a landscape element has an impact on the provision of a service (e.g. a large forested area can affect climate more than a small one). Despite the fact that the methodology used in this project for landscape services assessment largely stems from their work, this step was avoided, because their proposed procedure (re-categorization of area-weighted values by $20^{\text {th }}$. percentiles) did not consider the occurrence of very few large patches in opposition to many small ones, leading to biased results.

The rather small and insignificant differences between landscape services within and between the landscape types were caused by the aggregation of relevant subservices into main landscape services, which resulted in a loss of information. This obstacle seems to be the main drawback of the methodology, but it can be partly rectified by weighting individual sub-services, based on the need of landscape managers to stress particular sub-services.

\subsection{Relationships between structural functionality and landscape services}

Statistical analyses confirmed to some degree that landscapes with higher structural functionality could have a higher capacity to provide landscape services. However, this assertion was valid predominantly for the alluvial forested and upland meadow forested LTs, due to a higher occurrence of valuable landscape elements with a higher share of natural species that significantly influence many of the landscape subservices: this includes, among others, disturbance prevention, water regulation, and water supply, soil formation, nutrient regulation, genetic resources, raw materials, medicinal resources, science, and education (Yapp et al., 2010). This assertion is most likely influenced by the positive relationship between structural functionality and the majority of landscape metrics related to this functionality group (see Tab. 1). Positive relationships between the landscape/ ecosystem services and the landscape metrics that characterize the valuable matrix have also been reported in other studies: Lautenbach et al. (2011) found, for example, that food, recreation, and water regulation were affected by the size of the respective patch; Bodin et al. (2006) reported similar findings for pollination; and Frank et al. (2012) identified significant relationships between genetic resources and the nursery and shape index.

Negative relationships between structural functionality and many landscape sub-services in the hilly agricultural LT correspond to the prevalence of the disturbed matrix in this landscape type, and consequently indirectly point to the relation between sub-services, namely those from the provision and information services, and the respective landscape metrics. The relationships between functionality groups and landscape metrics also explain the negative outcome for habitation (typical of the artificial matrix) and transportation (typical of the dissecting corridors) sub-services in both forested LTs.

Because the relationships were only significant for some landscape services and in some landscape types, aggregating landscape metrics in order to deliver structural functionality values gives fuzzy results, and might be used only for some landscape services. It seems that combining only landscape metrics with landscape services can give a clearer picture about the importance of spatial configuration on estimating, evaluating, and maintaining landscape services (see Syrbe, Walz, 2012; $\mathrm{Su}$ et al., 2012; Lautenbach et al., 2011; or Frank et al., 2012), and therefore might be a better solution for landscape planners and managers.

\section{Conclusion}

This paper investigates two methods for assessing structural functionality and landscape services, and the potential of their joint application in order to estimate the impact of landscape structure in terms of structural functionality on landscape capacity to provide various landscape services.

The main advantage of the methods lies in the fact that all assessed criteria are spatially embedded and can be simply visualized, and therefore give a clear idea about potentials, possible conflicts and limits in landscape planning and management. Also, their relative simplicity and limited need for detailed data meet the requirement to be easily accessible and lowcost. The especially transparent sampling and selection procedures of landscape metrics used to define functionality groups ensures general applicability to other regions, and can be used in other landscape metric-related research questions.

Separately, the assessments can be used as supportive tools in nature conservation and landscape planning especially the assessment of structural connectivity, combined with tools incorporating species and other 
ecologically decisive driving factors, can, among other things, contribute to the delimitation of ecological networks or protected areas. The assessment of landscape services might help in evaluating sensitive regions, which was also demonstrated in the study published by Hermann et al. (2013). Another advantage of this assessment is in evaluating multiple services in one procedure, and thus capturing a more realistic picture of heterogeneous landscapes.

The results of the statistical analyses showed that linking structural functionality to landscape services might, to some extent, help in estimating the impact of landscape structure on some landscape services in landscape types with the prevalent valuable matrix, as were the cases of the upland meadow forested landscape type and the alluvial forested landscape type. However, the relation between these attributes very likely depends on the relationship between landscape metrics and structural functionality defined for the individual functionality groups. Therefore, a combination of individual landscape metrics with landscape services would probably provide better insights on how landscape structure can influence landscape services.

\section{Acknowledgements}

This article was generated by institutional support (VUKOZ-IP-00027073). The biotope layer used for assessing ecological stability was supplied by the Nature Conservation Agency of the Czech Republic.

\section{References:}

ANTROP, M. (2000): Background concepts for integrated landscape analysis. Agriculture, Ecosystems \& Environment, Vol. 77, p. 17-28.

BOCK, M. et al. (2005): Spatial indicators for nature conservation from European to local scale. Ecological Indicators, Vol. 5, p. 322-338.

BODIN, Ö., TENGÖ, M., NORMAN, A., LUNDBERG, J., ELMQVIST, T. (2006): The value of small size: loss of forest patches and ecological thresholds in Southern Madagascar. Ecological Applications, Vol. 16, p. 440-451.

BURKHARD, B., KROLL, F., MÜLLER, F., WINDHORST, W. (2009): Landscapes' capacities to provide ecosystem services - a concept for land-cover based assessment. Landscape Online, Vol. 15, p. 1-22.

CUSHMAN, S. A., MCGARIGAL, K., NEEL, M. C. (2008): Parsimony in landscape metrics: strength, universality and consistency. Ecological Indicators, Vol. 8, p. 691-703.

DAUBER, J. et al. (2003): Landscape structure as an indicator of biodiversity: matrix effects on species richness. Agriculture, Ecosystems \& Environment, Vol. 98, p. 321-329.

de GROOT, R. (2006): Function-analysis and valuation as a tool to assess land use conflicts in planning for sustainable, multifunctional landscapes. Landscape and Urban Planning, Vol. 75, p. 175-186.

de GROOT, R. S., WILSON, M. A., BOUMAND, R. M. J. (2002): A typology for the classification, description and valuation of ecosystem functions, goods and services. Ecological Economics, Vol. 41, p. 393-408.

DRAMSTAD, W. E., TVEIT, M. S., FJELLSTAD, W. J., FRY, G. L. A. (2006): Relationships between visual landscape preferences and map-based indicators of landscape structure. Landscape and Urban Planning, Vol. 78, p. 465-474.

ESRI, Inc. (1999-2008): ArcMap 9.3. Redlands, CA.

ESSL, F., EGGER, G., ELLMAUER, T., AIGNER , S. (2002): Rote Liste der gefährdeten Biotoptypen Österreichs: Konzept. UBA-Monographien, Umweltbundesamt, Wien. 40 pp.

FARIG, L. (2003): Effects of habitat fragmentation on biodiversity. Annual Review of Ecology, Evolution and Systematics, Vol. 34, p. 487-515.

FELD, C. K. et al. (2007): Assessing and monitoring ecosystems - indicators, concepts and their linkage to biodiversity and ecosystem services. The RUBICODE Project. 108 p. [online] available at: http://www.rubicode.net/rubicode/RUBICODE_ Review_on_Indicators.pdf

FORMAN, R. T. T., GODRON, M. (1986): Landscape Ecology. John Willey and Sons, Inc., New York, NY, USA. 619 pp.

FRANK, S., FÜRST, C., KOSCHKE, L., MAKESCHIN, F. (2012): A contribution towards a transfer of the ecosystem service concept to landscape planning using landscape metrics. Ecological Indicators, Vol. 21, p. 30-38.

HAINES-YOUNG, R., CHOPPING, M. (1996): Quantifying landscape structure: a review of landscape indices and their application to forested landscapes. Progress in Physical Geography, Vol. 20, p. 418-445.

HAINES-YOUNG, R., POTSCHIN, M. (2008): England's Terrestrial Ecosystem Services and the Ecosystem Approach. Full Technical Report. 89 pp. 
HERMANN, A. et al. (2013): Assessment framework for landscape services in European cultural landscapes: An Austrian Hungarian case study. Ecological Indicators. (In press).

HERMANN, A., SCHLEIFER, S., WRBKA, T. (2011): The concept of ecosystem services regarding landscape research: A review. Living Reviews in Landscape Research, Vol. 5, p. 1-37.

HOKIT, D. G., STITH, B. M., BRANCH, L. C. (1999): Effects of landscape structure in Florida scrub: A population perspective. Ecological Applications, Vol. 9, p. 124-134.

KONG, F., YIN, H., NAKAGOSHI, N. (2007): Using GIS and landscape metrics in the hedonic price modeling of the amenity vaule of urban green space: A case study in Jinan City, China. Landscape and Urban Planning, Vol. 79, p. 240-252.

KUIPER, J. (1998): Landscape quality based upon diversity, coherence and continuity: Landscape planning at different planning-levels in the River area of The Netherlands. Landscape and Urban Planning, Vol. 43, p. 91-104.

KUTTNER, M., HAINZ-RENETZEDER, C., HERMANN, A., WRBKA, T. (2013): Borders without barriers - Structural functionality and green infrastructure in the Austrian-Hungarian transboundary region of Lake Neusiedl. Ecological Indicators, Vol. 31, p. 59-72.

LAUTENBACH, S., KUGEL, C., LAUSCH, A., SEPPELT, R. (2011): Analysis of historic changes in regional ecosystem service provisioning using land use data. Ecological Indicators, Vol. 11, p. 676-687.

MCGARIGAL, K., CUSHMAN, S. A., NEEL, M., ENE, E. (2002): FRAGSTATS: spatial pattern analysis program for categorical maps. [online] Available at: http://www.umass.edu/landeco/research/fragstats/fragstats.html

MEA (2005): Ecosystems and Human Well-Being: Synthesis Report. Island Press, Washington, DC., 155 pp.

MOSER, B., JAEGER, A. G., TAPPEINER, U., TASSER, E., EISELT, B. (2007): Modification of the effective mesh size for measuring landscape fragmentation to solve the boundary problem. Landscape Ecology, Vol. 22, p. 447-459.

MÍCHAL, I. (1994): Ekologická stabilita. Veronica, Brno. 275 pp.

NAVEH, Z., LIEBERMAN, A. (1994): Landscape ecology, Theory and Applicaton. Springer-Verlag, USA, New York. 356 pp.

NG, C. N., XIE, Y. J., YU, X. J. (2013): Integrating landscape connectivity into the evaluation of ecosystem services for biodiversity conservation and its implications for landscape planning. Applied Geography, Vol. 42, p. 1-12.

NOVÁKOVÁ, J., SKALOŠ, J., KAŠPAROVÁ, I. (2006): Krajinná ekologie. Skripta ke cvičením. Lesnická práce, Kostelec nad Černými Lesy. $31 \mathrm{pp}$.

PELLANTOVÁ, J. [ed.] (1994): Metodika mapování krajiny pro potřeby ochrany přírody a krajiny ve smyslu zákona ČNR 114/92 Sb. ČÚOP Praha - Výzkumné a monitorovací pracoviště v Brně, Praha. 34 pp.

PETROVIČ, F. (2005): Vývoj krajiny v oblasti štálového osídlenia Pohronského Inovca a Tribeča. Ústav krajinnej ekológie SAV, pobočka Nitra, Bratislava. 209 pp.

POTSCHIN, M. (2009): Land use and the state of the natural environment. Land Use Policy, Vol. 26, p. S170-S177.

PUCHEROVÁ, Z. [ed.] (2007): Druhotná krajinná štruktúra (Metodická príručka k mapovaniu). UKF v Nitre, Nitra. 124 pp. RIITERS, K. H. et al. (1995): A factor analysis of landscape pattern and structure metrics. Landscape Ecology, Vol. 10, p. 29-39.

SEJÁK, J. et. al. (2010): Hodnocení funkcí a služeb ekosystémů České republiky. Fakulta životního prostředí UJEP v Ústí nad Labem, Ústí nad Labem. 198 pp.

SEPPELT, R. et al. (2012): Form follows function? Proposing a blueprint for ecosystem service assessments based on reviews and case studies. Ecological Indicators, Vol. 21, p. 145-154.

SHERROUSE, B. C., CLEMENT, J. M., SEMMENS, D. J. (2011): A GIS application for assessing, mapping, and quantifying the social values of ecosystem services. Applied Geography, Vol. 31, p. 748-760.

SCHINDLER, S., POIRAZIDIS, K., WRBKA, T. (2008): Towards a core set of landscape metrics for biodiversity assessments. A case study from Dadia National Park, Greece. Ecological Indicators, Vol. 8, p. 502-514.

SKOKANOVÁ, H., EREMIÁŠOVÁ, R. (2012): Changes in the secondary landscape structure and the connection to ecological stability: the cases of two model areas in the Czech Republic. Ekológia (Bratislava), Vol. 31, p. 33-45.

SKOKANOVÁ, H., EREMIÁŠOVÁ, R. (2013): Landscape functionality in protected and unprotected areas: Case studies from the Czech Republic. Ecological Informatics, Vol. 14, p. 71-74.

STATSOFT, Inc. (2004): STATISTICA Cz, version 10.0. Available at www.statsoft.cz.

SU, S., XIAO, R., JIANG, Z., ZHANG, Y. (2012): Characterizing landscape pattern and ecosystem services value changes for urbanization impacts at an eco-regional scale. Applied Geography, Vol. 34, p. 295-305.

SYRBE, R.-U., WALZ, U. (2012): Spatial indicators for the assessment of ecosystem services: Providing, benefitting and connecting areas and landscape metrics. Ecological Indicators, Vol. 21, p. 80-88. 
STEINHARDT, U., HERZOG, F., LAUSCH, A., MÜLLER, E., LEHMANN, S. (1999): Hemeroby index for landscape monitoring and evaluation. In: Hyatt, D.E., Lenz, R.J. [eds.]: Environmental indices - System analysis approach. EOLSS Publ., Oxford, pp. 237-254.

TERMORSHUIZEN, J., OPDAM, P. (2009): Landscape services as a bridge between landscape ecology and sustainable development. Landscape Ecology, Vol. 24, p. 1037-1052.

TISCHENDORF, L. (2001): Can landscape indices predict ecological processes consistently? Landscape Ecology, Vol. 16, p. 235-254.

TSCHARNTKE, T., STEFFAN-DEWENTER, I., KRUESS, A., THIES, C. (2002): Characteristics of insect populations on habitat fragments: A mini review. Ecological Research, Vol. 17, p. 229-239.

VAN DER HORST, D. (2011): Adoption of payments for ecosystem services: an application of the Hägerstrand model. Applied Geography, Vol. 31, p. 668-676.

VONDRUŠKOVÁ, H. [ed.] (1994): Metodika mapování krajiny. SMS Hradec Králové, Praha. 55 pp.

WAGNER, H. H., FORTIN, M. J. (2005): Analysis of landscapes: concepts and statistics. Ecology, Vol. 86, p. $1975-1987$.

WAINGER, L. A., KING, D. M, MACK, R. N., PRICE, E. W., MASLIN, T. (2010): Can the concept of ecosystem services be practially applied to improve natural resource managament decisions? Ecological Economics, Vol. 68, p. 978-987.

WALLACE, K. J. (2007): Classification of ecosystem services: Problems and solutions. Biological Conservation, Vol. 139, p. 235-246.

WEINSTOERFFER, J., GIRARDIN, P. (2000): Assessment of the contribution of land use pattern and intensity to landscape quality: use of a landscape indicator. Ecological Modelling, Vol. 130, p. 95-109.

WILlEMEN, L., VERBURG, P. H., HEIN, L., van MENSVOORT, M. E. F. (2008): Spatial characterization of landscape functions. Landscape and Urban Planning, Vol. 88, p. 34-43.

YAPP, G., WALKER, J., THACKWAY, R. (2010): Linking vegetation type and condition to ecosystem goods and services. Ecological Complexity, Vol. 7, p. 292-301.

\section{Author's address:}

Mgr. Hana SKOKANOVÁ, Ph.D.

Silva Tarouca Research Institute for Landscape and Ornamental Gardening, Pub. Res. Inst.

Lidická 25/27, 60200 Brno, Czech Republic

e-mail:hanka@skokan.net

Initial submission 25 May 2013, final acceptance 10 October 2013

Please cite this article as:

SKOKANOVÁ, H. (2013): Can we combine structural functionality and landscape services assessments in order to estimate the impact of landscape structure on landscape services? Moravian Geographical Reports, Vol. 21, No. 4, p. 2-15, DOI: 10.2478/mgr-2013-0016. 